\title{
Kreşe Giden 2-6 Yaş Arası Çocukların Ailelerin Tatil Kararları Üzerindeki Etkisi: Akçakoca Örneği *
}

\author{
Dr. Öğr. Üyesi Yıldırım YILDIRIM ** \\ Ezgi ASLANKAYA $* * *$
}

\begin{abstract}
Öz
Bu çalışma; daha önce alan yazında çok sık araştırılmayan 2-6 yaş arası çocukların, ailelerinin tatil kararları üzerinde etkisi olup olmadığını öğrenmek amacıyla yapılmıştır. Buna göre çocukların, ailelerin bazı kararları üzerinde etkili olduğu - özellikle kendileriyle doğrudan ilgili olan ürün ve hizmetlerde bu kararların daha baskın olarak çıktığı - bilinmektedir. Bu sebeple araştırmanın, sözü edilen yaş grubundaki çocukların satın alma davranışları ve karar sürecindeki yerlerini bilmek açısından önemli olacağı ve alana katkı sağlayacağı düşünülmektedir. Yapılan bu araştırma sonucunda evde tatil kararını veren kişinin demografik faktörlere göre değiştiği sonucuna ulaşılmıştır. Ayrıca tatil alt kararlarında çocuğun en fazla otel/pansiyon seçimi, tatil bölgesi seçimi ve gezilecek yerler/ aktiviteler konusunda dikkate alındığı, en az etkili olduğu konunun ise tatil bütçesinin belirlenmesi olduğu araştırma sonucunda ortaya çıkmıştır. Ayrıca ailelerin gelir düzeyleri, tek veya çift gelire sahip olmaları, yılda çıktıkları tatil sayıları, eğitim seviyeleri çocuğun tatil kararlarındaki etki düzeyini farklılaştırmaktadır.
\end{abstract}

Anahtar Kelimeler: Aile, 2-6 yaş arası çocuklar, Karar süreci, Tatil

\section{The Effects of 2-6 Years Old Children on Their Families' Holiday Decisions: The Case of Akçakoca}

\begin{abstract}
This study was conducted in order to find out whether the children of 2-6 years old, who have not been researched very frequently in the field, have an influence on their families' vacation decisions. Accordingly, it is known that children are influenced by some of their decisions - especially those products and services that are directly related to them. For this reason, we believe that the children in the age group of our research will be important in terms of knowing the purchasing behaviors and their place in the decision process and will contribute to the field. As a result of this research, according to the demographic factors, it is revealed that the person who made the holiday decision at home changed. It has been seen that the person making the holiday decision at home differs according to education level, number of children, family management style and family budget. In addition, in the sub-decisions of the holiday, the child has been mostly taken into consideration about the places will seen/ activities, choice of the hotel / pension and holiday region. It is seen that children of 2-6 years old have least affect on determination of the vacation budget. In addition, families' income and education levels, number of vacation planned per year and single or double incomes differentiate the level of
\end{abstract}

* Bu makale 26 Nisan 2018'de düzenlenen 17. Geleneksel Turizm Sempozyumunda sunulmuştur.

** - Düzce Üniversitesi, Akçakoca Turizm İşletmeciliği ve Otelcilik Yüksekokulu, yildirimyildirim@duzce.edu.tr

*** - Düzce Üniversitesi, Akçakoca Turizm İşletmeciliği ve Otelcilik Yüksekokulu, ezgiiaslankaya@gmail.com 
influence of children on vacation decisions.

Key words: Family, Children of 2-6 years old, decision process, holiday

\section{GİRIS}

Sosyal ve kültürel değişkenler arasında sayılan aile kavramı, tüketici davranışlarında konu olarak sıkça işlenmekte, ailenin tüketim davranışlarında rolü ve etkisinin olduğu araştırılmaktadır. Ailenin yapısı, ailedeki çocuk sayısı, çocukların yaşı, ailenin eğitim seviyesi, geliri, yaşam tarzı ve değerleri başı başına tüketim kararlarında ve çocuğun söz sahibi olmasında etkili olmaktadır (Nanda ve diğ., 2006; Therkelsen, 2010). Turizm konusunda da verilen tatil kararlarının toplumun en küçük birimi olan aileden etkilendiği ve aile bireylerinin yönlendirici etkisi olduğu belirtilmektedir (Lehto ve diğ., 2013). Özellikle ailedeki çocukların ebeveynleriyle birlikte seyahat deneyimini yaşamaları onların her geçen gün daha da önemini artırmış ve bu durum pazarlamacıların ve reklamcıların ilgisini çekerek 3 yaşından itibaren çocukların birer tüketici olarak görülmesine sebep olmuştur (Li, Wang, Xu ve Mao, 2017). Değişen ve modern yapıya kavuşan aile yapısı, geleneksek aile (ataerkil/anaerkil aile) yapılarından çok farklı özellikler sergilemekte ve bu özelliklerin ayırt ediciliği verilen tatil kararlarında daha da öne çıkmaktadır. Geniş aile yapısından çekirdek aile yapısına, oradan da tek eşli ailelere uzanan değişim, tüketim ve tatil kararlarında da değişime yol açmış ve çocukların etkisi artmıştır. Geleneksel aile yapılarında daha çok büyüklerin sözünün dinlenmesi, evde anane, babaanne ve dedenin bulunması verilen kararların yönünü etkilemekteydi. Fakat giderek küçülen aile yapıları sonucunda çocuklar ön plana çıkmaya başlamış ve özellikle Türk aile yapılarında meydana gelen dönüşümler pazarlamacıların çocuklar üzerine daha fazla eğilmesine neden olmuştur. Kadının profesyonel iş hayatında yer alması, meslek ayırt edilmeksizin her meslek grubunda kadınlarında aktif olarak rol alması (futbol hakemliği, ralli yarışçısı, güreş sporu, taksi/uzun yol şoförlüğü vs.) kadınların daha yoğun ve stres altında çalışmasına, buna bağlı olarak evden uzak kalmasına neden olmuş ve bu açığı kapatmak için çok daha fazla çocukların isteklerine kulak verilmiştir. Çocukların rasyonel düşünceden uzak olması ve yalnızca ısrar ederek, duygusal sömürü yaparak ve direterek ailelerine istedikleri ürün ve hizmeti aldırmaya çalışmaları onları geleceğin tüketicisi konumuna yükseltmiştir (Çakıcı ve İyitoğlu, 2012: 119).

$\mathrm{Bu}$ çalışmada çocukların ailelerin aldığı tatil kararlarında ne ölçüde etkili oldukları araştırılmıştır. 7 yaşından küçük çocukların etkilerinin araştırıldığı çalışma sayısının azlığı dikkate alındığında bu çalışmanın sonuçlarının literatürdeki boşluğu doldurması ve alana katkı sağlaması amaçlanmaktadır. Yerli ve yabancı alan yazında genellikle 9-11 yaş arası ile 11 yaş ve üzeri çocukların alınan tatil kararları üzerindeki etkileri araştırılmış ve sonucunda büyük yaş grubundaki çocukların küçük yaş grubundaki çocuklara nazaran tatil kararlarında çok daha fazla etkili oldukları sonucuna ulaşılmıştır (Wang ve diğ., 2004; Therkelsen, 2010; Chen ve diğ., 2015). Bu çalışmada ise 2-6 yaş arası çocukların olduğu anaokullarında ailelerle yüz yüze yapılan anket çalışması sonucu çocukların tatil 
kararlarına ne düzeyde etki ettikleri belirlenmeye çalışılmıştır. Araştırma sonuçlarının turizm alanında yöneticilik yapan akademisyen ve uygulayıcılara faydalı olması beklenmektir. Böylelikle otel yöneticileri çocuklu aile pazarından daha fazla pay alabilecek ve onların istek ve beklentileri doğru bir şekilde karşılanabilecektir.

\section{TURİZM PAZARLAMASINDA ÇOCUK VE AİLE}

Turizm pazarlamasında turistlerin davranışları sıklıkla araştırmacılar tarafından incelenmekte ve bu davranışların zaman içerisinde ne yönde değiştiği anlaşılmaya çalışılmaktadır. Turistlerin beklenti ve memnuniyetlerinin turizm işletmeleri için önemli olmasının nedeni turistlerin tatil yeri ile ilgili değerlendirmelerinin tek bir faktöre değil birden çok faktöre bağlı olmasıdır (Memiş, 2016: 213). Özellikle yapısal değişime uğrayan aile kavramı sosyoloji ve psikoloji bilim dalları kadar seyahat ve otel işletmeciliği, turizm pazarlaması ve tüketici davranışları gibi bilim dallarınca da incelenmekte ve ailenin seyahat nedenleri, verdiği satın alma kararlarında ağırlıklı olarak rolün kime ait olduğu öğrenilmeye çalışılmaktadır (Aymankuy ve Ceylan, 2013: 106; Li ve diğ., 2017: 3). Aile kavramı tüketici davranışlarını etkileyen sosyo-kültürel faktörler başlığı altında değerlendirilmekte ve tüketicilerin davranışlarını doğrudan etkileyebilmektedir. Toplumun en küçük yapı taşı olarak nitelendirilen aile, geçmişten günümüze büyük değişime uğramış ve bu değişimler karar mekanizmalarını da etkilemiştir. Geleneksel (ataerkil) ve geniş (kalabalık) aile yapılarından, çekirdek aile hatta tek/bekâr ebeveynli aile yapılarına olan dönüşüm, çocuklara ve onların birer tüketici olarak kimliklerine olan bakış açısını değiştirmiştir. Reklamcılar ve pazarlamacılar, giderek aile içerisinde önemi artan çocuklara birer tüketici gözüyle bakmaya başlamış ve erken yaşlardan itibaren tek başına karar alabileceklerini fark etmişlerdir (Aygün, 2006: 16). Özellikle annenin iş hayatına aktif katılımı sonucunda, çocuklar küçük yaşlardan itibaren kreşlere/ana okullara verilerek erken sosyalleşmeleri sağlanmış ve çocuklar birçok kararı kendi başlarına alabilmeyi öğrenmiştir. Bazı yazarlar aile yapısında zor beğenen ve kendi tercihleri olan çocukerkil bir döneme girildiğinden bahsetmektedir (Alagöz, 2009: 317). Bunun en temel uygulamaları otel işletmelerinde ortaya çıkmaktadır. Çocuklu ailelerin otel ve tatil yeri seçimindeki kriterleri bekârlardan ve çocuksuz ailelerden farklılaşmakta (Bronner ve de Hoog, 2008; Türedi, 2009) ve bu farklılık beklenen hizmetlere de yansımaktadır. Thornton ve arkadaşları da (1997), tatil deneyimlerinde çocuklu ve çocuksuz ailelerde birtakım farklılıklar olduğunu belirtmiştir. Örneğin, çocuklu aileler havuzda veya plajda daha çok zaman harcarken, çocuksuz aileler veya yetişkinler barlarda, gece kulüplerinde veya heyecan ve tehlike gerektiren aktivitelerde zaman geçirmektedirler.

Özellikle anne-babanın birlikte çalıştığı ailelerde çocuk çok daha uzun süre yalnız kalabilmekte ve aileler bu açığı kapatabilmek için çocuklarının istediklerini yapmaya daha hevesli olabilmektedirler. Çalışmalar, çocukların etki düzeyinin onların demografik özelliklerine bağlı olduğunu bulmuştur. Çifte gelirli (geleneksel olmayan) ailelerdeki çocukların aile kararlarında daha etkili olduğu düşünülmüştür (Labrecque ve Ricard, 
2001) çünkü ebeveynlerin daha fazla olan gelirleri, onların daha yoğun oldukları için daha meşgul hissetmelerini sağlamıştır. Çocuklarının isteklerini karşılarken daha fazla verdikleri görülmüştür. Hatta anne-babanın birlikte çalıştığ çocuklu ailelerde, ebeveynler çocuklarına sağladıkları finansal olanakları bir nevi manevi tazminat olarak gördükleri ve kendi kendilerini bu yolla rahatlattıkları iddia edilmektedir (Li ve diğ., 2017). Bu anlamda çocuklu ailelerin finansal yönden daha ağır sorumluluk altında olmaları, daha uzun süre hazırlık yapmaları ve çocuklarını kararlarında dikkate almaları onları ayrı birer pazar bölümü haline getirmiştir (Emir ve Pekyaman, 2010: 160). Çocuklu ailelerin yalnızca karar süreçlerini ve tatil kararlarında çocuklarını ne düzeyde dinlediklerini bilmek yeterli olmamaktadır. Aynı zamanda karar süreci aşamalarının hangisinde kimin daha etkin rolü olduğu da araştırılmalı ve farklı karar süreci aşamalarında farklı hedef kitleye uygun mesajlar geliştirilebilmelidir (Karadağ, 2011). Örneğin, ihtiyacın ortaya çıkması ve bilgi edinme aşamasında kim daha baskın, alternatifleri değerlendirme aşamasında veya satın alma/nihai karar verme aşamasında kimin rolü ağırlıklı bilinmeli ve farklı pazarlama bileşenleri ile yaklaşılmalıdır.

Bir aile tatili, aile bağının ve refahının kayda değer bir destekçisi olarak algılanmaktadır (Lehto, Choi, Lin ve MacDermid, 2009). Gevşeme ve günlük yaşam baskısından kaçma arzusuna ek olarak ebeveynler, tatil deneyimlerinin aileyi yeniden birbirine bağlamasını beklemekte (Li ve diğ., 2017), aile tatilinin bir nevi ailenin kültürel fotoğrafi olduğunu ve aileyi bir arada tuttuğunu ve hatırlanacak anı ve deneyimler yarattığını söylemektedir (Lehto ve diğ., 2013). Özellikle batı toplumunda aile tatilinin aidiyet ve birliktelikle özdeşleşmesi ve ailecek yapılan tatillerin aile bağlarının ve kimlik oluşumunun işlevsel bir aracı olarak kabul edildiği iddia edilmektedir (Hallman ve Benbow, 2007).

Yukarıdaki bilgiler ışığında aşağıdaki hipotezler geliştirilmiştir:

$\mathrm{H}_{1:}$ Çocuğu ilgilendiren tatil alt kararlarına ilişkin ortalamalar, çocuğu ilgilendirmeyen tatil alt kararlarına ilişkin ortalamalardan daha yüksektir.

$\mathrm{H}_{2:}$ Tatile çıkma kararını kimin verdiği ile demografik özellikler birbiri ile bağımlıdır.

$\mathrm{H}_{3:}$ Tatil alt kararları demografik özelliklere göre farklılık göstermektedir.

Ülkemizin sahip olduğu genç nüfusu ve yüksek doğum oranlarını da dikkate alarak nüfusumuzun önemli bir bölümünü çocukların oluşturduğunu (Alagöz, 2009: 320) ve günümüzde çocukların nesillerin devamı olarak değil de ekonomik bir değer olarak görülmeye başlandığını ve pazarlama alanında hedef grubu oluşturduğunu söyleyebiliriz (Gülerarslan, 2011: 126). Sayılarla ifade edildiğinde ülkemizde 0-14 yaş grubu çocukların toplam nüfus içindeki oranı yaklaşık \%26 (TUİK, 2018), dünya genelinde ise nüfusun \%30'unu oluşturmaktadır (Statista, 2020). Bu çalışma her ne kadar ailelerin verdikleri tatil kararlarında çocukların ne düzeyde etkili olduğunu araştırsa da, çocukların yalnızca tatil kararlarında değil, hemen hemen bütün ürünlerde verilecek kararlara ortak olduğunu, özellikle doğrudan çocukları ilgilendiren ürünlerde nihai kararı kendilerinin verdiğini 
görmekteyiz (Gülerarslan, 2011: 135; Karadağ, 2011: 89; Çakıcı ve İyitoğlu, 2011: 3). $\mathrm{Bu}$ sebeple geleneksel (ataerkil) ve modern (katılımcı - demokratik) aile yapılarından, çocukerkil aile yapılarına doğru hızlı bir geçiş yapıldığı birçok araştırmacı tarafından vurgulanmaktadır. Aşağıdaki tabloda çocuklara yönelik ürünlerin bir listesi verilmektedir. Çocuklar bu ürün gruplarında doğrudan aileleri üzerinde etkili olabilmekte ve kararlarını tek başlarına alabilmektedirler. Literatürde çocukların kendileriyle ilgili ürünlerin talebini doğrudan etkileyebileceğine dair bulgular vardır (bkz: Therkelsen, 2010; Lawlor ve Prothero, 2011; Webster, 2012). Çocuklara ilişkin ürünler yalnızca endüstriyel ürünlerle sınırlı değildir. Tatil deneyimi esnasında, çocuğun dikkatini çekecek yerler (temalı parklar, eğlence mekânları, hayvanat bahçesi, oyuncak ve teknoloji müzeleri gibi) ve bu yerlere giriş için alınan biletlerde birer ürün sayılabilmektedir. Ancak çocuklar, yalnızca kendileriyle ilgili ürünlerin talebini değil, diğer bütün satın alım kararlarını ve hemen hemen bütün ürün ve hizmet taleplerini doğrudan etkileyebilmektedirler. Dışarıda yemek yeme ve çocukların ailelerini bu konuda ne düzeyde etkilediklerine dair yapılan bir araştırmada restoran türü, restoran seçimi, yemek seçimi, ne zaman yemek yenileceği, yemek bütçesi, yemek fikrinin ortaya atılması ve bilgi toplama gibi karar sürecinin her aşamasında çocukların etkili olduğu sonucuna ulaşılmıştır (Chen ve diğ., 2015).

\section{Tablo 1. Çocuklara Yönelik Pazarda Sunulan Ürünler}

\begin{tabular}{|l|}
\hline Çocuklara yönelik üretim yapan tekstil ürünleri (baskılı tişörtler vs.) \\
\hline Çocuk kitapları, masallar, hikâyeler, süreli yayınlar \\
\hline Oyuncak süpermarketleri \\
\hline Diğer kırtasiye ürünleri (kalem, silgi, defter, dosya, kitap ayracı vs.) \\
\hline Alışveriş merkezlerindeki oyun ve eğlence alanları \\
\hline Sinema endüstrisi ürünleri \\
\hline Temizlik ürünleri (özel diş macunları, diş firçaları, şampuan, krem vs.) \\
\hline Hazır gıda işletmelerinin çocuk menüleri \\
\hline Sakız, çikolata, şeker, jelibon ve bisküvilerin çocuklara yönelik ambalajları \\
\hline Makarna, yoğurt, süt (meyveli yoğurtlar, meyveli sütler, renkli makarnalar) \\
\hline Çizgi film karakterli ambalaja sarılmış su şişeleri \\
\hline Çocuk mobilyaları, perdeler, desenli, kabartmalı çocuk halıları \\
\hline Akülü arabalar, bisikletler, scooter ve kaykaylar \\
\hline Televizyon kanalları (sadece çizgi film veren tematik kanallar) \\
\hline
\end{tabular}

Kaynak: Gülerarslan, A. (2011). Tüketici Olarak Çocuk ve Ailenin Satın Alma Kararlarına Etkisi, Selçuk Üniversitesi İletişim Fakültesi Dergisi, 6(4), ss.126-137 


\section{2-6 YAŞ ARASI ÇOCUKLARIN DÖNEM ÖZELLİKLERİ}

Okul öncesi yılları içine alan erken çocukluk ya da ilk çocukluk dönemi, 2-6 yaş arasındaki çocuğun aktif olarak çevresine yöneldiği, uyarıcılar ile dış dünyayı keşfetmeye çalıştığı, insan yaşamının en temel becerilerinin kazanıldığı bir dönemdir (Bacıoğlu, 2017: 130). Bu dönemdeki çocukların yetişkinlerden farklı, kendine özgü bir düşünme ve akıl yürütme biçimlerinin olmasıdır. İşlem öncesi döneme özgü bu düşünme biçimi; olayların büyülü ve doğaüstü bir niteliği olduğunu düşünme, özelden özele akıl yürütme, benmerkezci düşünme, cansız nesnelere canlı özelliği yükleme, canlı ve cansız ayrımı yapamama, olayların yalnızca bir yönüne odaklanma gibi çeşitli zihinsel görüntülerle kendini göstermektedir. (İnanç, Bilgin ve Atıc1, 2015: 121). Piaget’ye göre (2003), mantıksal düşünme işlemi bu dönemde gelişmemiştir. Bu dönemde çocuklar nesnelerin görünüşünün etkisi altındadırlar. Henüz korunum (değişmezlik) için gerekli zihinsel kavrama sürecinden yoksundurlar. Korunum ilkesini kazanmış bir birey, herhangi bir nesnenin şeklinin değişmesinin etkisi altında kalmaksızın onun aynı kaldığını anlayabilir (Yavuzer, 1987). Bu dönemde motor becerileriyle zihinsel yeteneklerine dair gelişimlerini sürdüren çocuklar, çevreyi araştırmaya, pek çok şeyi denemeye devam eder, plan yapıp planları uygulamada daha çok sorumluluk üstlenebilirler. Çocuklar, öz bakım becerileri açısından daha iyi durumdadırlar. Anne-baba-çocuk ilişkisinin niteliği, bu dönemde gerçekleşmekte olan toplumsallaşma süreci açısından önemlidir (İnanç, Bilgin ve Atıcı, 2015: 43, 71). İçinde büyüdügü ailenin sosyal yapısı ve biçimi, çocuğun gelişiminde etkilidir (Yavuzer, 1987). Çocuğun isteğine tümüyle uyan ana-babalar, çocuğun sınır tanımayan istekleriyle karşılaşabilirler. Çocuğa bir derece özgürlük tanıyarak kendi istediklerini yapmasına olanak sağlamak, fakat bunu ölçülü bir biçimde yaparak çocuğu tamamıyla başıboş bırakmamak, gerçekleştirilmesi zor bir görevdir. Bu devrede ana-baba, çocuğu hem ezmeden hem de başıboș bırakmadan zor dengeyi kurmaya çalıșır (Cüceloğlu, 2012).

Okul öncesi dönemde şekillenen çocuğun sosyal ve duygusal gelişimi üzerinde, anne baba ve çocuk etkileşiminin niteliği büyük önem taşıdığından anne ve babanın çocuklarına dengeli, kararlı ve tutarlı davranmaları gerekmektedir. Anne babalar çocuklarının sosyal ve duygusal gelişiminde uygun ve sağlıklı birer özdeşim modeli olacak şekilde davranmalı, çocuklarının yaş ve gelişim özelliklerine uygun beklentiler taşımalıdırlar (Kandır ve Alpan, 2008). Çocuğun davranışlarını ailenin etkileyişinde, çocuğun sahip olduğu özellikleriyle yaşı büyük rol oynar. Çocuğun yaşı küçük olduğu oranda, aile üyelerinin daha etkili olmalarına karşılık yaş büyüdükçe aile dışı bireylerin ve arkadaşlarının etkisi giderek artmakta aile üyelerinin etkisi ise azalmaktadır (Yavuzer, 1987).

Nüfusun önemli bir bölümünü oluşturan çocuklar artık sadece nesillerin devamı açısından değil, ekonomik açıdan da önem arz eder duruma gelmiştir. Günümüzde çocuklar ekonominin itici gücü olarak görülmekte ve pazarlama alanında önemli bir hedef grubu oluşturmaktadır (Gülerarslan,2011). John (1999), 3-7 yaş arası dönemi algısal evre olarak adlandırıp, bu dönemde çocuğun pazarın hızlı ve kolayca algılanabilen özelliklerine odaklanabileceğini söylemektedir. Çocukların yaşlarına göre pazarı algılayışları ve pazarla ilgili sahip oldukları bilgi düzeyleri farklılık göstermektedir. Örneğin küçük yaşlarda 
sınırlı bilgiye sahip olan çocuklar için en önemli unsur ürünün dış görünüşüyken, daha ileriki yaşlarda ürünün kalitesi, markası önem kazanmaktadır (Madran ve Bozyiğit, 2013). Yaşlarının büyümesiyle birlikte çocukların analitik düşünme kapasitesi gelişmektedir. Böylece çocukların ürünler, fiyatlar, markalar ve reklamlar hakkındaki bilgileri ve deneyimleri artmakta, ailenin satın alma kararlarında daha fazla rol almaktadırlar (Ateşoğlu ve Türkkahraman, 2009). Çocukların alışveriş yapmayı öğrenmeleri veya pazarda tüketici haline gelmeleri kendiliğinden gerçekleşen bir olgu değildir. Çocuklar bu davranışları çeşitli faktörler sonucunda ve bir süreç içerisinde öğrenmektedirler (Madran ve Bozyiğit, 2013). Çocukların tüketici olarak sosyalleşmesinde etkili olan sosyalleşme araçları aile, arkadaş grubu, okul, kitle iletişim araçları, perakendeciler ve markalardır. Aile, çocuğun tüketim konusundaki bilgisi, tutumu ve yeteneğini kazanmasında en önemli sosyalleşme aracıdır. Aile, çocuğa harçlık vererek parayı nasıl harcamaları gerektiği, nereden alışveriş yapması gerektiğini, markalar ve fiyat - kalite ilişkisi gibi tüketim ve tüketime dair bilgileri öğretir (Ateşoğlu ve Türkkahraman, 2009) Çocuğun istek ve tercihleri, ebeveynler üzerinde reklam gibi pazarlama iletişimi çabalarından çoğu kez daha etkili olabilmektedir. Pazarlama mesajlarına karşı duyarlılıkları, reklam izlemeye isteklilikleri, reklam müziklerini, karakterlerini, sloganlarını akılda tutma ve paylaşma yetileri, öykülenmeye yatkınlıkları, akranlarından etkilenme ve onları etkileme becerileri gibi faktörler bu kitleyi pazarlamacıların gözünde, "kanaat önderleri” haline getirmiş bulunmaktadır. Çocukların, özellikle aile kararlarına etkisi incelenirken kentsoylu- taşralı, eğitimli- eğitimsiz ebeveyn, kardeş sayısı, aile yapısı, algı ve zekâ kapasitesi ve daha birçok değişkenin hesaba katılması gerektiği unutulmamalıdır (Gülerarslan, 2011). Yüksek gelir düzeyine sahip ailelerin çocukları maddi imkânları daha elverişli olduğundan dolayı daha erken yaşlarda tüketici olarak sosyalleşmektedirler. Ayrıca kız çocukları da erkek çocuklarına oranla daha erken yaşta alışverişe başlamakta ve daha fazla oranda alışverişe gitmektedirler (Madran ve Bozyiğit, 2013).

\section{ARAŞTIRMANIN AMACI}

Günümüzde tatil pazarının yaklaşık üçte birini aile tatil pazarı oluşturmakta ve giderek önemini artırmaktadır. Bu nedenle, bu pazar bölümünün tatil kararlarına ilişkin daha fazla ve daha net bilgiye ihtiyaç duyulmaktadır (Çakıcı ve İyitoğlu, 2012: 117). Aile karar alma süreçleriyle ilgili yapılan çalışmalar genellikle ailelerin tüm üyelerinin birlikte, sadece anne-baba birlikte veya ebeveynlerden sadece herhangi birisinin baskın tutumuyla alınan kararlar şeklinde bazı teorilere dayandırılmaktadır (Karadağ, 2011: 74). Bu nedenle bu araştırmanın amacı, ailenin verdiği tatil kararlarında 7 yaş altı çocukların ne düzeyde etkili olduğunu öğrenmektir. Ayrıca çocuklu ailelerin bazı tatil alt kararlarında çocuklarını ne kadar dinledikleri ve tatile çıkma kararının demografik faktörlerle bir ilişkisinin olup olmadığının öğrenilmesi de araştırmanın amaçları arasındadır. 


\section{ARAŞTIRMANIN YÖNTEMİ}

Araştırmada veri toplama yöntemi olarak anket kullanılmış ve 2-6 yaş arası anaokulu ve kreşte bulunan çocukların ailelerine 5 Mart - 16 Mart 2018 tarihleri arasında 2 haftalık bir sürede uygulanmıştır. Araştırmanın evreni Akçakoca'da bulunan milli eğitime bağlı 5 anaokulu ve 1 özel kreşte eğitim gören 2-6 yaş arasındaki toplam 411 öğrencinin annebabasıdır. Araştırmada örneklem seçmek yerine, anaokulları ve kreşte bulunan çocukların ebeveynlerinin tamamına anket verilmiş olup tamsayım yöntemi uygulanmıştır. 3 hafta boyunca kreş ve anaokullarındaki görevli öğretmenlerden yardım alarak çocuklara verilen anketlerin anne-babalarına ulaştırılması sağlanmış, unutulan veya kaybolan anketlerin yerine yenileri verilmiştir. Hatalı/eksik veya yanlış cevaplanan anketlerin analize dâhil edilmemesi sonucunda 255 anket sağlıklı ve analize elverişli olarak değerlendirilebilmiștir. Ankette toplam 35 soru bulunmakta olup, bunların ilk sekiz tanesi demografik bilgileri (yaş, cinsiyet, medeni hal, çocuk sayısı, gelir seviyesi, eğitim düzeyi, meslek, aile bütçesi, aile yapısı ve aile yönetimini) öğrenmeye yönelik sorulardır. Sonraki sorular ise yılda çıkılan tatil sayısı, tatile çıkma kararını kimin verdiği, tatile sıklıkla nereye gidildiği ve tatil alt kararlarında (tatil süresi, tatil bütçesi, kalınacak gün sayısı, bölge seçimi vs.) çocukların ne düzeyde etkili olduğunu öğrenmeye yönelik sorulardır. Tatil alt kararlarında çocuğun etki düzeyi anne-babalara sorulmuş ve $0=$ hiç etkili değil ile $5=$ oldukça etkili arasında her bir tatil alt kararı için bir tercih yapmaları istenmiştir. Anketin sonunda tatil kararlarında çocukların etkisini öğrenmeye yönelik 5'li Likert Ölçeğine göre sorulmuş 21 ifade Emir ve Pekyaman (2010), Çakıcı ve İyitoğlu (2011, 2012), Aymankuy ve Ceylan’ın (2013) çalışmalarından istifade edilerek oluşturulmuş ve cevaplayıcıların bu ifadelere $1=$ Kesinlikle katılmıyorum, 5=Kesinlikle katılıyorum şeklinde 1'den 5'e kadar olan aralıkta cevap vermeleri istenmiştir. İfadelerin anlaşılabilirliğinin belirlenmesi için uzman akademisyenlerden yardım alınmış, ayrıca 30 kişilik bir grupla ön çalışma yapılarak ölçeğin geçerliliği sorgulanmıştır. Aşağıda araştırma yapılan okulların listesi ve sahip oldukları öğrenci sayıları gösterilmektedir. Bu bilgiler Akçakoca İlçe Milli Eğitim Müdürlüğünden alınmış olup, araştırmanın yapıldığı eğitim dönemindeki sayıları ifade etmektedir. Araştırmanın kısıtları, az sayıda hatasız anketle araştırmanın yapılmış olması ve yalnızca Akçakoca'da yapılmış olmasıdır. Dolayısıyla sonuçların tüm Türkiye için genellenmesi mümkün değildir. Ayrıca araştırma çocukların kendisi ile değil annebabalarıyla gerçekleştirilmiştir. Dolayısıyla bazı zamanlarda çocukların gerçek istek ve beklentilerinin anne-babalarının varsayımlarından farklı olabileceği unutulmamalıdır. Ebeveynlerin çocuklarıyla ilgili bildiklerini düşündükleri ve çocuklarının aile tatilinde sevdiği ve sevmediği şeyler arasında büyük uçurumlar olabilir (Henderson ve diğ., 2007) 
Tablo 2. Akçakoca’da Bulunan ve Araştırmanın Yapıldığı Anaokulları ve Kreşler

\begin{tabular}{cccc}
\hline Okul adı & Derslik sayısı & Öğretmen sayısı & Ö̆̆renci sayısı \\
Birsen Güçlü Ana Okulu & 5 & 6 & 100 \\
Akçakoca Ana Okulu & 5 & 6 & 87 \\
Seher Fedai Karabıyık A.O. & 5 & 4 & 63 \\
Ayazlı Ana Okulu & 5 & 5 & 60 \\
Esvet Dilek Sarıŏlu A.O. & 5 & 3 & 59 \\
Özel Birce Kreşi & 4 & 3 & 42 \\
Toplam & 29 & 27 & $\mathbf{4 1 1}$ \\
\hline
\end{tabular}

\section{ARAŞTIRMANIN BULGULARI}

Aşağıdaki tabloda ankete katılanların demografik bilgilerine ilişkin (yaş, cinsiyet, eğitim, gelir, meslek, çocuk sayısı, aile bütçesi, aile yapısı vs.) dağılım gösterilmiştir. Ayrıca yılda çıkılan tatil sayısı, hangi mevsimin tercih edildiği, katılımcıların aile yönetim şekillerinin ne olduğu, tatile çıkma kararının kim tarafından verildiği ve tatile sıklıkla nereye gidildiğine dair sorular ve bu soruların cevaplarına ilişkin frekans ve yüzdelik dağılımlarda yer almaktadır. 
Tablo 3. Demografik Değişkenlere İlişkin Yüzdelik Dağılımlar

\begin{tabular}{|c|c|c|c|}
\hline Değişkenler & Cevap Seçenekleri & Frekans & Yüzde \% \\
\hline \multirow{4}{*}{ Yaş } & 30 yaş altı & 57 & 22,4 \\
\hline & $31-40$ yaş & 144 & 56,5 \\
\hline & $41-50$ yaş & 40 & 15,7 \\
\hline & 50 yaş üstü & 14 & 5,5 \\
\hline \multirow{2}{*}{ Cinsiyet } & Kadın/Anne & 155 & 60,8 \\
\hline & Erkek/Baba & 100 & 39,2 \\
\hline \multirow{4}{*}{ Eğitim durumu } & İlköğretim & 59 & 23,1 \\
\hline & Lise & 91 & 35,7 \\
\hline & Lisans & 95 & 37,3 \\
\hline & Lisansüstü & 10 & 3,9 \\
\hline \multirow{3}{*}{ Mesleğiniz / İşiniz } & Kamu görevlisi & 61 & 23,9 \\
\hline & Özel sektör & 99 & 38,8 \\
\hline & Diğer & 95 & 37,3 \\
\hline \multirow{4}{*}{ Hane halk1 geliri } & $1.000-2.000 \mathrm{TL}$ & 65 & 25,5 \\
\hline & $2.001-3.000 \mathrm{TL}$ & 84 & 32,9 \\
\hline & $3.001-4.000 \mathrm{TL}$ & 70 & 27,5 \\
\hline & 4.000 TL üstü & 36 & 14,1 \\
\hline \multirow{4}{*}{ Çocuk sayınız } & 1 & 69 & 27,1 \\
\hline & 2 & 141 & 55,3 \\
\hline & 3 & 39 & 15,3 \\
\hline & 3'ten fazla & 6 & 2,4 \\
\hline \multirow{2}{*}{ Aile bütçeniz } & Tek maaş & 147 & 57,6 \\
\hline & Çift maaş & 108 & 42,4 \\
\hline \multirow{2}{*}{ Aile yapınız } & Çekirdek aile & 223 & 87,5 \\
\hline & Geniş aile & 32 & 12,5 \\
\hline
\end{tabular}

Yukarıdaki tabloda katılımcıların büyük çoğunluğunun 31-40 yaş arasında, kadın, lisans düzeyinde eğitime sahip, 2.001-3.000 TL arası gelirli özel sektör çalışanlarından oluştuğu görülmektedir. Ayrıca katılımcıların büyük çoğunluğu çekirdek aile yapısında olup, 2 çocuğa sahiptir ve evde yalnız bir kişi çalışmaktadır (anne veya baba). Bu sebepten "tek maaş" seçeneği en çok işaretlenen seçenek olmuştur. 
Tablo 4. Diğer Değişkenlere İlişkin Yüzdelik Dağılımlar

\begin{tabular}{|c|c|c|c|}
\hline Değişkenler & Cevap Seçenekleri & Frekans & Yüzde \% \\
\hline \multirow{5}{*}{$\begin{array}{l}\text { Tatile çıkma kara- } \\
\text { rı kim tarafından } \\
\text { verilmektedir }\end{array}$} & Anne & 24 & 9,4 \\
\hline & Baba & 42 & 16,5 \\
\hline & Çocuk & 3 & 1,2 \\
\hline & Anne-baba ortak & 95 & 37,3 \\
\hline & Anne-baba-çocuk ortak & 91 & 35,7 \\
\hline \multirow{5}{*}{$\begin{array}{c}\text { Tatile siklıkla } \\
\text { nereye gidersiniz }\end{array}$} & $\begin{array}{c}\text { Memlekete / Büyüklerin } \\
\text { yanına }\end{array}$ & 118 & 46,3 \\
\hline & 5 yıldızlı otele & 58 & 22,7 \\
\hline & $\begin{array}{c}\text { Kamp kuracağımız yeşil } \\
\text { alanlara }\end{array}$ & 10 & 3,9 \\
\hline & Tatil köyüne & 42 & 16,5 \\
\hline & Pansiyon/Apart otele & 27 & 10,6 \\
\hline \multirow{2}{*}{$\begin{array}{l}\text { Tercih edilen tatil } \\
\text { mevsimi }\end{array}$} & Yaz & 228 & 89,4 \\
\hline & $\mathrm{K}_{1 S ̧}$ & 27 & 10,6 \\
\hline \multirow{4}{*}{$\begin{array}{l}\text { Yılda çıktığınız } \\
\text { tatil sayısı }\end{array}$} & 1 & 159 & 69,1 \\
\hline & 2 & 46 & 20,0 \\
\hline & 3 & 9 & 3,9 \\
\hline & 3'ten fazla & 16 & 7,0 \\
\hline \multirow[t]{2}{*}{ Aile yönetiminiz } & Demokratik aile & 202 & 79,2 \\
\hline & Ataerkil aile & 53 & 20,8 \\
\hline
\end{tabular}

Tatile çıkma kararının evde kim tarafından verildiği sorulduğunda katılımcıların büyük çoğunluğu anne-baba ortak şeklinde yanıt vermiştir. Ancak Anne-baba-çocuk ortak $(\% 35,7)$ seçeneği de yalnızca anne-baba $(\% 37,3)$ seçeneğine oldukça yakın olduğundan tatil ile ilgili kararların evde demokratik bir ortam içerisinde alındığı ve bunda çocuğunda payı bulunduğu bulgulara dayanarak söylenebilir. Zira "nasıl bir aile yönetiminiz var?" şeklindeki soruya katılımcıların neredeyse \%80'i biz demokratik bir aileyiz cevabını vermişlerdir. Tercih edilen tatil mevsimine bakıldığında ankete katılanlar büyük çoğunlukla yaz aylarını tercih ettiklerini belirtmiştir. Kış aylarında tatile çıkanların oranı \%10 civarında gerçekleşmiştir. Katılımcıların \%69'u yılda 1 kez tatile çıktığını söylerken, \%20'si yılda 2 kez çıktığını söylemiştir. Üçüncü sırada yılda 3’ten fazla tatile çıkanlar bulunmaktadir.

\subsection{Normallik Testi}

Araştırmalarda Anova, T-testi, Ki-kare, Regresyon gibi parametrik testler kullanabilmek 
için ön koşulları sağlamak gerekir. Örneğin, Anova testi için varyansların homojen olması, verilerin normal dağılması ve örneklemin rast gele seçilmesi gerekir. Bu ön koşullardan birinin sağlanamadığı durumlarda parametrik olmayan testler kullanılmalıdır. Verilerin normal dağılıp dağılmadığını ölçmek için basıklık (kurtosis) ve çarpıklık (skewness) değerlerine bakılır (Altunışık vd., 2010). Tabachnick ve Fidell (2013) bu değerlerin $-1,5$ ile $+1,5$ arasında olduğu durumlarda verilerin normal dağılıma uyduğunun kabul edilebileceğini söylemektedir. Bazı yazarlar bu değerlerin -2 ile +2 arasında olabileceğini belirtmiştir (George ve Mallery, 2000). Bu varsayımdan hareketle çalışmada Anova, T-testi, Ki-kare gibi parametrik testler kullanılabilir.

\section{Tablo 5. Tatil Alt Kararlarına İlişkin Basıklık ve Çarpıklık Değerleri}

\begin{tabular}{|c|c|c|}
\hline Tatil Alt Kararları & İstatistik & Sonuç \\
\hline \multirow{2}{*}{ Tatil bütçesinin ne olacağı } & Çarpıklık &,- 050 \\
\cline { 2 - 3 } & Basıklık & $-1,297$ \\
\hline \multirow{2}{*}{ Tatilde yapılacak aktiviteler/gezilecek yerler } & Çarpıklık &,- 912 \\
\cline { 2 - 3 } & Basıklık &, 413 \\
\hline \multirow{2}{*}{ Tatil için otel/pansiyon seçimi } & Çarpıklık &,- 679 \\
\cline { 2 - 3 } & Basıklık &,- 691 \\
\hline \multirow{2}{*}{ Tatilde kalınacak gün sayısı } & Çarpıklık &,- 613 \\
\cline { 2 - 3 } & Basıklık &,- 565 \\
\hline \multirow{2}{*}{ Ulaşım kararı (araba, uçak vs.) } & Çarpıklık &,- 378 \\
\cline { 2 - 3 } & Basıklık & $-1,170$ \\
\hline \multirow{2}{*}{ Tatile ne zaman çıkılacağı } & Çarpıklık &,- 499 \\
\cline { 2 - 3 } & Basıklık &,- 773 \\
\hline \multirow{2}{*}{ Tatile kimlerle gidileceği } & Çarpıklık &,- 421 \\
\cline { 2 - 3 } & Basıklık &,- 839 \\
\hline \multirow{2}{*}{ Tatil bölgesi seçimi } & Çarpıklık &,- 613 \\
\cline { 2 - 3 } & Basıklık &,- 725 \\
\hline
\end{tabular}

Yukarıdaki tabloda araştırmada kullanılan ölçeklerde ortaya çıkan basıklık ve çarpıklık değerleri gösterilmektedir. Araştırmanın okuyuculara kolaylık sağlaması ve uzunluk açısından olumsuz yaratmaması ve analizlerde kullanılmadığ için 21 soruluk ifadenin basıklık çarpıklık değerleri verilmemiştir. Ancak yapılan analiz sonucunda değerlerin normallik varsayımı dışına çıkmadığı ve $-1,5$ ile $+1,5$ arasında olduğu gözlemlenmiştir. 
Tablo 5. Tatil Alt Kararlarında Çocuğun Etki Düzeyi

\begin{tabular}{lcccc}
\hline & Ort. & Mod & $\begin{array}{c}\text { St. } \\
\text { Sapma }\end{array}$ & $\begin{array}{c}\text { Cronbach } \\
\text { Alfa (8 ifade) }\end{array}$ \\
Tatil bütçesinin ne olacağ1 & 2,26 & 0 & 1,776 & \\
Tatilde yapılacak aktiviteler/gezilecek yerler & 3,60 & 4 & 1,293 & \\
Tatil için otel/pansiyon seçimi & 3,15 & 5 & 1,669 & 0,878 \\
Tatilde kalınacak gün sayısı & 3,12 & 4 & 1,551 & \\
Ulaşım kararı (araba, uçak, tren, otobüs vs.) & 2,88 & 5 & 1,792 & \\
Tatile ne zaman çıkılacağ1 & 2,96 & 3 & 1,643 & \\
Tatile kimlerle gidileceği & 2,89 & 3 & 1,649 & \\
Tatil bölgesi seçimi & 3,11 & 4 & 1,636 & \\
\hline
\end{tabular}

Tatile çıkma kararı hızlı verilebilen ve yalnızca basit bir karardan ibaret değildir. Tatile çıarken birden fazla alt karar tüketicilerin nihai kararını etkilemekte ve yönlendirebilmektedir. Yukarıdaki tabloda tatile çıkma kararında göz önüne alınan bazı alt unsurlarda çocuğun ne düzeyde etkili olabileceğine dair ifadeler sorulmuş ve katılımcıların bu ifadeleri $0=$ hiç etkisi yok ile $5=$ çok fazla etkili arasında puanlaması istenmiştir. Buna göre ailelerin tatil ile ilgili verdikleri alt kararlarda çocuğun düşüncesini en fazla önemsedikleri konular otel/pansiyon seçimi ile ulaşım kararı olmuştur. Bunu sırasıyla tatilde yapılacak aktiviteler/gezilecek yerler ile tatil bölgesinin seçimi kararları takip etmiştir. Aileler en çok bu konularda çocuklarının düşüncelerini önemsediklerini ve çocuklarının bu kararlarda oldukça fazla etkili olduğunu belirtmişlerdir. Çocuğun etkisinin hiç olmadığı konuların başında ise tatil bütçesinin kararlaştırılması gelmektedir. Tabloda ortalama ile birlikte mod unsurunun kullanılmasının nedeni cevaplar arasındaki değişimi daha rahat görebilmek ve ortalama değerden ne kadar uzak ya da ne kadar yakın dağıldıkları hakkında bilgi edinebilmektir. Tablo 5 'te mod'u 4 olan tatil bölgesi seçimi, kalınacak gün sayısı ve yapılacak aktiviteler ifadelerinin ortalaması, mod'u 5 olan ulaşım kararı ifadesinin ortalamasından büyük çıkmıştır. Buna göre en sık tekrarlanan değer olan mod, bütün verilerden etkilenmemekte ve araştırmacıya verilen cevapların değişimi hakkında daha ayrıntılı fikir verebilmektedir. Aileler tatil bütçesi belirlerken çocuklarını dikkate almamakta ve çocuklar bu konularda etkili olamamaktadırlar. Buna göre $\mathrm{H}_{1}$ hipotezi kabul edilebilir. 
Tablo 6. Tatile Çıkma Kararını Veren ile Demografik Faktörler Arasındaki Bağıntıyı Belirlemeye Yönelik Ki-Kare Analizi

\begin{tabular}{ccc}
\hline & Demografik Değişkenler & p değeri \\
\cline { 2 - 3 } & Eğitim düzeyi & $\mathbf{0 , 0 0 6}$ (bağıntı var) \\
Meslek & 0,431 (bağıntı yok) \\
Yaş & 0,096 (bağıntı yok) \\
Tatile çıkma kararını & Cinsiyet & 0,283 (bağıntı yok) \\
kimin verdiği & Gelir seviyesi & 0,356 (bağıntı yok) \\
& Aile Yönetim şekli & $\mathbf{0 , 0 0 0}$ (bağıntı var) \\
& Aile yapısı & 0,621 (bağıntı yok) \\
& Aile bütçesi & $\mathbf{0 , 0 0 7}$ (bağıntı var) \\
& Çocuk sayısı & $\mathbf{0 , 0 4 7}$ (bağıntı var) \\
\hline
\end{tabular}

Tatile çıkma kararını veren kişinin demografik faktörlere göre değişip değişmediğini, diğer bir ifadeyle tatile çıkma kararını veren kişiyle demografik faktörler arasında bir ilişki olup olmadığını ortaya çıkarmak amacıyla yapılan ki-kare analizi sonucunda katılımcıların eğitim düzeyi, aile yönetim şekilleri ve sahip oldukları aile bütçesine göre tatil kararını veren kişinin değiştiği ve bunlar arasında istatistiksel olarak anlamlı bir ilişkinin olduğu görülmüştür. Yapılan çapraz tablo analizleri sonucunda örneğin eğitim seviyesi düştükçe ailede tatil kararının tek kişi tarafından verildiği, benzer şekilde demokratik ailelerde kararın ortak alındığını ancak aile yönetimi olarak ataerkil yapıya sahip olan ailelerde kararın çoğunlukla baba tarafından verildiği görülmüştür. Çocuk sayısına göre incelendiğinde, tek çocuklu ailelerin birden fazla çocuğu olan ailelere göre daha katılımcı bir karar süreci işlettikleri görülmektedir. Çocuk sayısı arttığında çocuğun tatil kararındaki etkisi azalmakta ve karar yetkisi daha çok anne-baba ortak veya sadece baba şeklinde gerçekleşmektedir. Maaş durumuna göre incelendiğinde, tek maaşlı ailelerde çocuğunda dahil olduğu bir karar süreci işlerken, çift maaşlı (anne ve babanın birlikte çalıştığı) ailelerde ise karar ebeveynler tarafından verilmektedir. Buna göre tek maaşlı ailelerin çift maaşlı ailelere göre çocuğu daha fazla dikkate aldıkları ve karar sürecine dâhil ettikleri söylenebilir. Yaş, cinsiyet, gelir seviyesi, meslek, aile yapısı (çekirdek - geniş aile) ve çocuk sayısı ile tatile çıkma kararını veren kişi değişkeni arasında anlamlı bir ilişkiye rastlanmamıştır. Buna göre $\mathrm{H}_{2}$ hipotezi kısmende olsa kabul edilebilir. 
Tablo 7. Tatil Alt Kararlara İlişkin Ortalamaların Demografik Faktörlere Göre Farkını Belirlemeye Yönelik ANOVA Analizi

\begin{tabular}{|c|c|c|c|c|c|c|c|}
\hline & Grup & $\mathbf{N}$ & Ort & Ss & $\mathbf{F}$ & p & Fark \\
\hline \multirow{11}{*}{$\begin{array}{c}\text { Tatil alt kararlarına } \\
\text { ilişkin ortalamalar } \\
\text { (tatil bütçesi, tatil } \\
\text { zamanı, ulaşım } \\
\text { kararı, otel seçimi, } \\
\text { tatilde gidilecek } \\
\text { yerler vs.) }\end{array}$} & $1.000-2.000 \mathrm{TL}$ & 65 & 2,52 & 1,260 & \multirow{4}{*}{6,275} & \multirow{4}{*}{$\mathbf{0 , 0 0 0}$} & \multirow{4}{*}{$\begin{array}{l}4>1 \\
4>3 \\
3>1\end{array}$} \\
\hline & $2.001-3.000 \mathrm{TL}$ & 84 & 3,00 & 1,139 & & & \\
\hline & $3.001-4.000 \mathrm{TL}$ & 70 & 3,20 & 1,130 & & & \\
\hline & 4.000 TL üstü & 36 & 3,47 & 1,135 & & & \\
\hline & Tek maaş & 147 & 2,75 & 1,233 & \multirow{2}{*}{15,677} & \multirow{2}{*}{$\mathbf{0 , 0 0 0}$} & \multirow{2}{*}{$2>1$} \\
\hline & Çift maaş & 108 & 3,34 & 1,081 & & & \\
\hline & $\begin{array}{l}\text { Memlekete/Büyüklerin } \\
\text { yanına }\end{array}$ & 118 & 2,71 & 1,347 & \multirow{5}{*}{3,669} & \multirow{5}{*}{0,006} & \multirow{5}{*}{$\begin{array}{l}2>1 \\
2>3 \\
2>4 \\
4>1 \\
4>3\end{array}$} \\
\hline & 5 y1ldizlı otele & 58 & 3,33 & 1,071 & & & \\
\hline & $\begin{array}{l}\text { Kamp kuracağımız yeşil } \\
\text { alanlara }\end{array}$ & 10 & 2,98 & 0,780 & & & \\
\hline & Tatil köyüne & 42 & 3,32 & 0,992 & & & \\
\hline & Pansiyona/Apart otele & 27 & 3,03 & 0,966 & & & \\
\hline
\end{tabular}

Tatil alt kararlara ilişkin ortalamaların demografik faktörlere göre değişip değişmediğini belirlemek için yapılan Anova analizi sonucunda gelir seviyesi, aile bütçesi, çocuk sayısı ve tatilde gidilen yere göre ortalamalar itibariyle gruplar arasında farklar olduğu görülmüştür. Buna göre, gelir seviyesi yüksek olan kişilerin kararlarında çocuklarının etki düzeyi yüksekken, gelir seviyesi azaldıkça çocukların kararlara olan etkisi de azaldığ 1 görülmüştür. Yine, çift maaşlı kişilerin tek maaşlı olanlara göre, tatile yılda birden fazla çıkanların ise tatile daha az çıkanlara göre tatil alt kararlarına ilişkin ortalamaları daha yüksek bulunuştur. Tatilde memlekete/büyüklerinin yanına gidenler en düşük ortalamaya sahipken, 5 yıldızlı otele ve tatil köyüne gidenlerin tatil alt kararlarına ilişkin ortalamaları daha yüksektir. Yaş, cinsiyet, meslek, çocuk sayısı ve aile yapısı ile tatil alt kararları arasında ortalamalar itibariyle bir fark gözlemlenmemiştir. Buna göre $\mathrm{H}_{3}$ hipotezi kabul edilebilir.

Tablo 8. Tatil Alt Kararlarının Eğitim Düzeyine Göre Farkını Belirlemeye Yönelik Kruskal Wallis H Testi

\begin{tabular}{|l|c|}
\hline & Tatil Alt Kararları \\
\hline Chi-Square & 9,170 \\
\hline df & 3 \\
\hline Asymp. Sig. &, 027 \\
\hline
\end{tabular}

Yukarıda her ne kadar verilere ilişkin çarpıklık ve basıklık değerlerine göre değerlendirme yapıp verilerin normal dağıldığını söylesekte, bu durum Anova analizinde farklı gruplara ayrılan verilerin ayrı ayrı normal dağılım gösterdiğini kanıtlamamaktadır. Eğitim düzeyi ile yılda çıkılan tatil sayısı değişkenlerine ait gruplarda kişi sayısının 30'un altında olması dolayısı ile verilerin normal dağılmadığı varsayılmıştır. Tatil alt kararlarında çocuğun etki düzeyinin eğitim seviyesine göre farklılaşıp farklılaşmadığını öğrenmek için parametrik 
olmayan Kruskal Wallis $\mathrm{H}$ testi yapılmış olup, anlamlı farklılık çıktığı için $\left(\chi^{2}=9,170 \mathrm{df}=3\right.$ ve $\mathrm{p}=0,027)$ hangi gruplar arasında farklılı̆̆ın olduğunu belirlemek için Mann Whitney U testi yapılmıştır. Eğitim seviyesine ilişkin analizler aşağıdaki gibidir. Anlamlı çıkan ikili gruplar aşağıda sırasıyla tablo olarak gösterilmiştir.

\subsection{Tatil alt kararlarının ilköğretim ile lisans eğitim düzeylerine göre farkı}

\begin{tabular}{|l|c|c|c|c|c|c|}
\hline & \multicolumn{6}{|c|}{ Mann Whitney U Testi Sonuçları } \\
\cline { 1 - 5 } Eğitim düzeyi & $\mathrm{N}$ & Sıralama Ort. & Siralama Top. & U değeri & Z değeri & P \\
\hline İlköğretim & 59 & 68,27 & 4028 & 2258 & $-2,025$ & 0,043 \\
\hline Lisans & 95 & 83,23 & 7907 & & & \\
\hline
\end{tabular}

Yapılan Mann Whitney U testine göre ilköğretim ile lisans eğitim düzeyleri arasında tatil alt kararları bakımından anlamlı farklılıklar vardır. Lisans eğitim düzeyine sahip kişilerin tatil alt kararlarında çocuklarını ilköğretim eğitim seviyesine sahip kişilere göre çok daha fazla dinlemektedirler.

\subsection{Tatil alt kararlarının ilköğretim ile lisansüstü eğitim düzeylerine göre farkı}

\begin{tabular}{|l|c|c|c|c|c|c|}
\hline & \multicolumn{6}{|c|}{ Mann Whitney U Testi Sonuçları } \\
\hline Eğitim düzeyi & $\mathrm{N}$ & Sıralama Ort. & Sıralama Top. & U değeri & Z değeri & $\mathrm{P}$ \\
\hline İlköğretim & 59 & 32,73 & 1931 & 161 & $-2,287$ & 0,022 \\
\cline { 1 - 4 } Lisans üstü & 10 & 48,40 & 484 & & & \\
\hline
\end{tabular}

Yapılan Mann Whitney U testine göre ilköğretim ile lisansüstü eğitim düzeyleri arasında tatil alt kararları bakımından anlamlı farklılıklar vardır. Lisansüstü eğitim düzeyine sahip kişilerin tatil alt kararlarında çocuklarını ilköğretim eğitim seviyesine sahip kişilere göre çok daha fazla dinledikleri görülmektedir.

\subsection{Tatil alt kararlarının lise ile lisansüstü eğitim düzeylerine göre farkı}

\begin{tabular}{|l|c|c|c|c|c|c|}
\hline & \multicolumn{6}{|c|}{ Mann Whitney U Testi Sonuçları } \\
\hline Eğitim düzeyi & $\mathrm{N}$ & Siralama Ort. & Siralama Top. & U değeri & Z değeri & P \\
\hline Lise & 91 & 48,92 & 4452 & 266 & $-2,151$ & 0,031 \\
\hline Lisansüstü & 10 & 69,90 & 699 & & & \\
\hline
\end{tabular}

Yapılan Mann Whitney U testine göre lise ile lisansüstü eğitim düzeyleri arasında tatil alt kararları bakımından anlamlı farklılıklar vardır. Lisansüstü eğitim düzeyine sahip kişilerin tatil alt kararlarında çocuklarını ilköğretim eğitim seviyesine sahip kişilere göre çok daha fazla dinledikleri görülmektedir. 
Tablo 9. Tatil Alt Kararlarının Yılda Çıkılan Tatil Sayısına Göre Farkını Belirlemeye Yönelik Kruskal Wallis H Testi

\begin{tabular}{|l|c|}
\hline & Tatil Alt Kararları \\
\hline Chi-Square & 27,309 \\
\hline df & 3 \\
\hline Asymp. Sig. &, 000 \\
\hline
\end{tabular}

Benzer şekilde tatil alt kararlarında çocuğun etki düzeyinin yılda çıkılan tatil sayısına göre farklılaşıp farklılaşmadığını öğrenmek için parametrik olmayan Kruskal Wallis H testi yapılmış olup, anlamlı farklılık çıktığ 1 için $\left(\chi^{2}=27,309 \mathrm{df}=3\right.$ ve $\left.\mathrm{p}=0,000\right)$ hangi gruplar arasında farklılığın olduğunu belirlemek için Mann Whitney U testi yapılmıştır.

\subsection{Tatil alt kararlarının yılda çıkılan tatil sayısına göre farkı}

\begin{tabular}{|l|c|c|c|c|c|c|}
\hline & \multicolumn{6}{|c|}{ Mann Whitney U Testi Sonuçları } \\
\cline { 1 - 5 } Y1lda çıkılan tatil & $\mathrm{N}$ & Siralama Ort. & Siralama Top. & U değeri & Z değeri & $\mathrm{P}$ \\
\hline 1 kere & 172 & 104,86 & 18036,50 & 3158,500 & $-4,025$ & 0,000 \\
\cline { 1 - 5 } 2 kere & 57 & 145,59 & 8298,50 & & & \\
\hline
\end{tabular}

Yapılan Mann Whitney U testine göre yılda çıkılan tatil sayısına göre tatil alt kararlarında çocuğun kararlara katılımı farklılaşmaktadır. Buna göre yılda iki kere tatile çıkanlar yılda bir kere tatile çıkanlara göre tatil alt kararlarda çocuklarını daha fazla dikkate almaktadırlar. Sıralamaların ortalamalarına bakıldığında yılda iki kere tatile çıkanların ortalamalarının yılda bir kere tatile çıkanlardan daha yüksek olduğu tablodan anlaşılmaktadır.

\subsection{Tatil alt kararlarının yılda çıkılan tatil sayısına göre farkı}

\begin{tabular}{|l|c|c|c|c|c|c|}
\hline & \multicolumn{6}{|c|}{ Mann Whitney U Testi Sonuçları } \\
\cline { 1 - 5 } Y1lda çıkılan tatil & $\mathrm{N}$ & Siralama Ort. & Siralama Top. & U değeri & Z değeri & $\mathrm{P}$ \\
\hline 1 kere & 172 & 89,03 & 15313,5 & 435,5 & $-2,211$ & 0,027 \\
\hline 3 kere & 9 & 128,61 & 1157,5 & & & \\
\hline
\end{tabular}

Yapılan Mann Whitney U testine göre yılda çıkılan tatil sayısına göre tatil alt kararlarında çocuğun kararlara katılımı farklılaşmaktadır. Buna göre yılda üç kere tatile çıkanlar yılda bir kere tatile çıkanlara göre tatil alt kararlarda çocuklarını daha fazla dikkate almaktadırlar. Sıralamaların ortalamalarına bakıldığında yılda üç kere tatile çıkanların ortalamalarının yılda bir kere tatile çıkanlardan daha yüksek olduğu tablodan anlaşılmaktadır. Buna göre tatile çıkma sayısı arttıkça çocukların tatil kararlarındaki etkisi artmaktadır. 
9.3. Tatil alt kararlarının yılda çıkılan tatil sayısına göre farkı

\begin{tabular}{|l|c|c|c|c|c|c|}
\hline & \multicolumn{6}{|c|}{ Mann Whitney U Testi Sonuçları } \\
\cline { 1 - 5 } Yılda çıkılan tatil & $\mathrm{N}$ & Siralama Ort. & Siralama Top. & U değeri & Z değeri & $\mathrm{P}$ \\
\hline 1 kere & 172 & 90,55 & 15574,5 & 696,5 & $-3,560$ & 0,000 \\
\cline { 1 - 4 } 3'ten fazla & 17 & 140,03 & 2380,5 & & & \\
\hline
\end{tabular}

Yapılan Mann Whitney U testine göre yılda çıkılan tatil sayısına göre tatil alt kararlarında çocuğun kararlara katılımı farklılaşmaktadır. Buna göre yılda üç kereden fazla tatile çıkanlar yılda bir kere tatile çıkanlara göre tatil alt kararlarda çocuklarını daha fazla dikkate almaktadırlar. Sıralamaların ortalamalarına bakıldığında yılda üç kereden fazla tatile çıkanların ortalamalarının yılda bir kere tatile çıkanlardan daha yüksek olduğu tablodan anlaşılmaktadır. Buna göre tatile çıkma sayısı arttıkça çocukların tatil kararlarındaki etkisi artmaktadir. 


\section{Tablo 10. Tatil Kararlarında Çocukların Etkisini Öğrenmeye Yönelik İfadelerin} Frekans ve Yüzdelik Dağılımları

\begin{tabular}{|c|c|c|c|c|c|c|c|c|c|c|c|c|}
\hline \multirow[t]{2}{*}{$\begin{array}{l}\text { Tatil Kararlarında Çocukların Etkisini } \\
\text { Öğrenmeye Yönelik İfadeler }\end{array}$} & \multicolumn{2}{|c|}{ 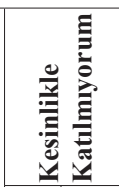 } & \multicolumn{2}{|c|}{ 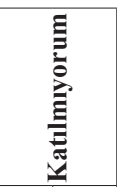 } & \multicolumn{2}{|c|}{ 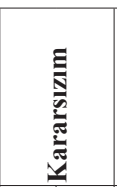 } & \multicolumn{2}{|c|}{ E } & \multicolumn{2}{|c|}{ 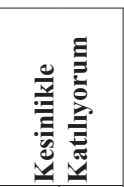 } & \multirow[t]{2}{*}{ Ort. } & \multirow[t]{2}{*}{ Ss } \\
\hline & f & $\%$ & f & $\%$ & f & $\%$ & f & $\%$ & f & $\%$ & & \\
\hline $\begin{array}{l}\text { Tatil kararlarımızda çocuklara özel indirim- } \\
\text { ler gidilecek yer tercihimizi etkiler }\end{array}$ & 13 & 5,1 & 25 & 9,8 & 25 & 9,8 & 119 & 46,7 & 73 & 28,6 & 3,83 & 1,10 \\
\hline $\begin{array}{l}\text { 12-13 yaşa kadar olan çocuklardan ücret } \\
\text { alınmayan otelleri tercih ederiz }\end{array}$ & 9 & 3,5 & 44 & 17,3 & 34 & 13,3 & 91 & 35,7 & 77 & 30,2 & 3,71 & 1,16 \\
\hline $\begin{array}{l}\text { Çocuklarımızla katıldığımız aktivitelerde } \\
\text { çocuk indirimi olmasını isteriz }\end{array}$ & 10 & 3,9 & 19 & 7,5 & 25 & 9,8 & 109 & 42,7 & 92 & 36,1 & 3,99 & 1,05 \\
\hline $\begin{array}{l}\text { Çocuklarımızın özel günlerinde onlara } \\
\text { özel indirimler uygulanmasını isteriz }\end{array}$ & 13 & 5,1 & 22 & 8,6 & 38 & 14,9 & 97 & 38,0 & 85 & 33,3 & 3,85 & 1,12 \\
\hline $\begin{array}{l}\text { Çocuklara özel aktivitelerin ve } \\
\text { animasyonların olması tatil yeri } \\
\text { tercihimizi etkiler }\end{array}$ & 9 & 3,5 & 20 & 7,8 & 24 & 9,4 & 92 & 36,1 & 110 & 43,1 & 4,07 & 1,07 \\
\hline $\begin{array}{l}\text { Çocuklara uygun havuzun ve su } \\
\text { kaydırağının olması gidilecek yer } \\
\text { tercihimizi etkiler }\end{array}$ & 13 & 5,1 & 15 & 5,9 & 27 & 10,6 & 101 & 39,6 & 99 & 38,8 & 4,01 & 1,09 \\
\hline $\begin{array}{l}\text { Çocuklara uygun spor aktivitelerinin } \\
\text { olduğu yerleri tercih ederiz }\end{array}$ & 10 & 3,9 & 17 & 6,7 & 31 & 12,2 & 96 & 37,6 & 101 & 39,6 & 4,02 & 1,06 \\
\hline $\begin{array}{l}\text { Kendimizden ziyade tatilde çocuğumuzun } \\
\text { eğlenmesini/mutlu olmasını isteriz }\end{array}$ & 8 & 3,1 & 16 & 6,3 & 28 & 11,0 & 81 & 31,8 & 122 & 47,8 & 4,14 & 1,05 \\
\hline $\begin{array}{l}\text { Tatil kararlarımızda çocuğumuzun bol } \\
\text { bol koşup oynayacağı açık alanları tercih } \\
\text { ederiz }\end{array}$ & 4 & 1,6 & 17 & 6,7 & 18 & 7,1 & 101 & 39,6 & 115 & 45,1 & 4,20 & 0,94 \\
\hline $\begin{array}{l}\text { Tatil kararlarımızda çocuğumuzun gezerek } \\
\text { öğreneceği yerleri tercih ederiz }\end{array}$ & 11 & 4,3 & 25 & 9,8 & 31 & 12,2 & 104 & 40,8 & 84 & 32,9 & 3,88 & 1,10 \\
\hline $\begin{array}{l}\text { Tatil yeri seçerken çocuğumuzdan dolayı } \\
\text { uzak olmayan yerleri tercih ederiz }\end{array}$ & 20 & 7,8 & 65 & 25,5 & 48 & 18,8 & 83 & 32,5 & 39 & 15,3 & 3,21 & 1,20 \\
\hline $\begin{array}{l}\text { Tatil yapılacak oteli çocuklarımızla birlikte } \\
\text { seçeriz }\end{array}$ & 12 & 4,7 & 48 & 18,8 & 50 & 19,6 & 108 & 42,4 & 37 & 14,5 & 3,43 & 1,09 \\
\hline $\begin{array}{l}\text { Otel seçiminde çocuklarımızın web sitesi } \\
\text { üzerinden oteli beğenmesi önemlidir }\end{array}$ & 16 & 6,3 & 52 & 20,4 & 55 & 21,6 & 90 & 35,3 & 42 & 16,5 & 3,35 & 1,16 \\
\hline $\begin{array}{l}\text { Tatil sonrası çocuklarımızla otele ilişkin } \\
\text { genel bir değerlendirme yaparız }\end{array}$ & 13 & 5,1 & 29 & 11,4 & 31 & 12,2 & 134 & 52,5 & 48 & 18,8 & 3,68 & 1,06 \\
\hline $\begin{array}{l}\text { Çocuklar için aile odalarının bulunduğu } \\
\text { otelleri tercih ederiz }\end{array}$ & 9 & 3,5 & 23 & 9,0 & 26 & 10,2 & 113 & 44,3 & 84 & 32,9 & 3,94 & 1,05 \\
\hline $\begin{array}{l}\text { Çocuklar için özel yemek saatleri ve } \\
\text { sağlıklı menülerin olduğu otelleri tercih } \\
\text { ederiz }\end{array}$ & 9 & 3,5 & 24 & 9,4 & 29 & 11,4 & 103 & 40,4 & 90 & 35,3 & 3,94 & 1,07 \\
\hline $\begin{array}{l}\text { Çocuk bakıcılığı hizmetlerinin olduğu } \\
\text { yerler otel tercihimizi etkiler }\end{array}$ & 23 & 9,0 & 58 & 22,7 & 57 & 22,4 & 73 & 28,6 & 44 & 17,3 & 3,22 & 1,23 \\
\hline $\begin{array}{l}\text { Tatilde çocuğumun istediği şeyleri satın } \\
\text { almak hoşuma gider }\end{array}$ & 15 & 5,9 & 30 & 11,8 & 52 & 20,4 & 99 & 38,8 & 59 & 23,1 & 3,61 & 1,13 \\
\hline $\begin{array}{l}\text { Tatildeki harcamalarımın büyük çoğunlu- } \\
\text { ğunu çocuklarım oluşturur }\end{array}$ & 9 & 3,5 & 44 & 17,3 & 45 & 17,6 & 93 & 36,5 & 64 & 25,1 & 3,62 & 1,13 \\
\hline $\begin{array}{l}\text { Otelin çocuklara ilişkin bazı hizmetleri } \\
\text { ücretli olsa bile yararlanırım }\end{array}$ & 15 & 5,9 & 18 & 7,1 & 54 & 21,2 & 116 & 45,5 & 52 & 20,4 & 3,67 & 1,06 \\
\hline $\begin{array}{l}\text { Çocuğumun tatil sonrası hatırlayacağı } \\
\text { birkaç eșya almak hoșuma gider }\end{array}$ & 5 & 2,0 & 18 & 7,1 & 17 & 6,7 & 103 & 44,3 & 102 & 40,0 & 4,13 & 0,95 \\
\hline
\end{tabular}


Yukarıdaki tabloda ailelerin tatil kararlarında çocuklarını hangi konularda dikkate aldıklarını ve onların tatilden ne beklediklerini ne düzeyde önemsediklerini öğrenmeye yönelik sorulmuş 21 ifadenin ortalama ve standart sapma değerleri ile frekans ve yüzdelik dağılımları gösterilmektedir. Buna göre ortalamaları 4'ün üzerinde olan ifadelere bakıldığında ailelerin daha çok tatilyeri seçimi, tatilde yapılacak aktiviteler, gezilip görülecek yerler ve turistik ürün satın alma konusunda çocuklarını önemsedikleri görülmektedir. "Çocuklara özel aktivitelerin ve animasyonların olması tatil yeri tercihimizi etkiler ( $\overline{\mathrm{x}}$ : 4,07)", "Çocuklara uygun havuzun ve su kaydırağının olması gidilecek yer tercihimizi etkiler ( $\overline{\mathrm{x}}$ : 4,01)", "Çocuklara uygun spor aktivitelerinin olduğu yerleri tercih ederiz $(4,02)$ ", "Kendimizden ziyade tatilde çocuğumuzun eğlenmesini/mutlu olmasını isteriz ( $\overline{\mathrm{x}}$ : 4,14)", "Tatil kararlarımızda çocuğumuzun bol bol koşup oynayacağı açı alanları tercih

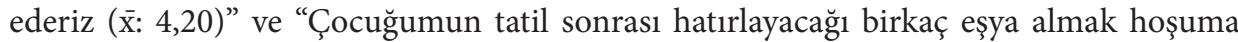
gider ( $\overline{\mathrm{x}}$ : 4,13)" ifadelerinin en yüksek ortalamaya sahip olduğu görülmektedir. Aileler ayrıca otelde aile odalarının olmasını, çocuklara özel yemek saatlerinin ve çocuklara özel indirimlerin olmasını önemsemektedir. En düşük ortalamaya sahip ifadelerin ise "Tatil yeri seçerken çocuğumuzdan dolayı uzak olmayan yerleri tercih ederiz ( $\bar{x}: 3,21)$ ", "Çocuk bakıcılığı hizmetlerinin olduğu yerler otel tercihimizi etkiler ( $\bar{x}: 3,22)$ ", "Otel seçiminde çocuklarımızın web sitesi üzerinden oteli beğenmesi önemlidir $(\bar{x}: 3,35)$ " ve “Tatil yapılacak oteli çocuklarımızla birlikte seçeriz ( $\bar{x}: 3,43)$ ” olduğu görülmektedir. Buna göre aileler otelde bakıcı hizmeti olup olmadığını, gidilecek destinasyonun uzak olup olmamasını ve otelin web sitesini çocukların önceden görüp görmemesini önemsememektedir.

\section{SONUÇ VE ÖNERİLER}

$\mathrm{Bu}$ araştırmada 7 yaş altı çocukların tatil kararlarındaki etkisini belirlemek ve aileleri üzerinde ne düzeyde etkili olduklarını ortaya koymak amaçlanmıştır. Alan yazındaki önceki çalışmalara bakıldığında sıklıkla 9-11 yaş arası ile 11 yaş ve üzeri çocuklarla araştırma yapıldığı ve bu araştırmada olduğu gibi 2-6 yaş arası çocuklar üzerinde yapılmış bir araştırmanın olmadığı veya yetersiz sayıda olduğu anlaşılmıştır (Li ve diğ., 2017). $\mathrm{Bu}$ sebeple araştırmanın alan yazına katkı sağlaması beklenmektedir. Tatil kararları ailelerin üzerinde düşündüğü ve kontrol edilemeyen birçok faktörün etkisi altında verilen kararlar olduğu bilinmektedir. Hele ki çocuklu aileler, seyahat, dinlenme, gezip-görme ve işin stresini atma amaçlarının yanı sıra çocuklarının eğlenmesini, gelişmelerine katkı sağlamayı ve sosyalleşmesini de önemsemektedirler. Çocuksuz ailelere göre çocuklu ailelerin tatilden bekledikleri faydaların farklı olduğu birçok araştırma tarafından vurgulanmaktadır. Karar sürecinin daha uzun sürmesi, bu karar sürecine çocukların da katılıyor olması tatil planlarını etkileyebilmekte ve bütünüyle değiştirebilmektedir.

Çocuklu ailelerin tatil kararlarında 7 yaş altı çocuklarını ne kadar dikkate aldıklarını belirlemek için yapılan bu araştırmada önceki çalışmaların sonuçlarıyla benzer ve o 
sonuçları destekler bulgulara rastlanmıştır. 2-6 yaş arası çocukların aileleriyle yapılan uygulama sonucunda ailelerin en fazla otel/pansiyon seçimi, tatil bölgesinin belirlenmesi, tatilde kalınacak gün sayısı, ulaşım kararı ve tatilde yapılacak aktiviteler, gezilecek/ görülecek yerler konusunda çocuklarını dikkate aldıkları görülmektedir. Turizm pazarlaması alanında yapılan birçok araştırma, çocukların aile satın alımlarını genellikle karar verme sürecinin çeşitli aşamalarında ve birçok tatil alt kararında etkilediğini ortaya koymuştur (Carr, 2006; Nanda ve diğ., 2007; Tripathi ve Sengupta, 2011; Jeevananda ve Kumar, 2012). Ailelerin çocuklarını en az dikkate aldıkları konu ise tatil bütçesinin belirlenmesi olmuştur. Thornton, Shaw ve Williams (1997), yaptıkları çalışma sonucunda, çocukların tatilde harcanacak para konusunda fazla söz sahibi olmadıklarını tespit etmişlerdir. Benzer şekilde Segumpan ve arkadaşları (2008), genel olarak, çocukların tatil sırasında aile harcamalarını belirlemede etkili olmadığı sonucuna ulaşmışlardır. Tatile çıkma kararını kimin verdiği sorusuna en büyük yüzdeyle anne-baba ortak cevabı verilirken, bunu sırasılyla anne-baba-çocuk ortak ve yalnızca baba seçenekleri takip etmektedir. Çinli aileler ve onların tatil kararları üzerinde yapılan bir araştırma sonuçları da bizdeki bulguları desteklemektedir. Araştırma sonucunda tatil karar verme sürecinde karar vericilerin çoğu anne-baba olarak ortaya çıkmıştır (Lehto, Fu, Li ve Zhao, 2013). Hindistan'da aile tatil kararını kimin verdiğiyle ilgili bir çalışmada da aile tatil sürecinin çoğunlukla ortaklaşa olduğu sonucuna ulaşılmıştır (Ashraf ve Khan, 2016). Geçmiş çalışmalarda, ailece yapılacak tatil kararlarında üç karar verme biçimi olduğu belirtilmektedir: kocanın baskın olduğu, kadının baskın olduğu ve ortak kararın alındığ karar verme biçimi (Khoo-Lattimore, Prayag ve Cheah, 2015). Bu karar biçimlerinden biri olan ortak karar zamanla yerini çocuğun baskın olduğu karar biçimine bırakmış ve çocuk ailenin hem tatil hem de diğer satın alımlarında karar mercii durumuna yükselmiştir.

Tatilde sıklıkla nereye gidersiniz sorusuna katılımcıların büyük çoğunluğu memleketebüyüklerin yanına cevabını vermiştir. İkinci sırada 5 yıldızlı otele, üçüncü sırada ise tatil köyüne gideriz cevapları gelmektedir. En düşük yüzdeye kamp kuracağımız yeşil alanlar cevabı sahiptir. Türk aile yapısının ve gelenek/göreneklerinin bir sonucu olarak karşımıza çlkan memleket ziyaretleri ve hala deniz-kum-güneş üçgeni çerçevesinde tercihlerimizi yapmamız, tatilden ne anladığımızı açıkça ortaya koymaktadır. Ashraf ve Khan (2016) aile kararlarının ve karar süreçlerinin kültürel rol beklentisi teorisinden etkilendiğini ve karı-koca rollerinin kültürün bir parçası ve mevcut kültürel adet ve geleneklerin bir işlevi olduğunu söylemektedir. Türk kültüründe de hala egemen olan büyükleri ziyaret etmek, yıllık izinleri ve tatilleri onların yanında geçirmek anlayışı çalışmamızda da tatil karar süreçlerini etkilemiştir. Katılımcıların \%90'ına yakını tatil mevsimi olarak yazı tercih ettiklerini belirtmiştir. Kış mevsiminde tatile çıkmayı tercih edenlerin oranı \%10,6'dır. Lehto ve diğerleri (2013), yaptıkları araştırmada ailelerin en popüler tatil mevsimi olarak ilkbaharı gördüklerini, bunu sırasıyla yaz, sonbahar ve kışın takip ettiğini bulmuşlardır. Kış mevsimi tatille ilgili yapılan çalışmalarda en az ilgi gören mevsim olarak karşımıza çıkmaktadır. Ailelerin yine büyük çoğunluğu kendilerini demokratik bir aile olarak tanımlamaktadır. Ancak yine de \%20’lik bir kısım geleneksel/ataerkil bir aile yapısına sahip olduklarını belirtmişlerdir. 
Tatile çıkma kararını veren kişinin kim olduğu ile demografik faktörler arasında bir ilişki olup olmadığı Ki-kare analiziyle incelenmiş ve tatile çıkma kararını veren kişinin eğitim seviyesine, çocuk sayısına, ailenin yönetim şekline ve aile bütçesine göre değiştiği sonucuna ulaşılmıştır. Buna göre eğitim seviyesi düştükçe ailede tatil kararının tek kişi tarafından verildiği, benzer şekilde demokratik ailelerde kararın ortak alındığını ancak aile yönetimi olarak ataerkil yapıya sahip olan ailelerde kararın çoğunlukla baba tarafından verildiği görülmüştür. Çocuk sayısına göre incelendiğinde, tek çocuklu ailelerin birden fazla çocuğu olan ailelere göre daha katılımcı bir karar süreci işlettikleri görülmektedir. Çocuk sayısı arttığında çocuğun tatil kararındaki etkisi azalmakta ve karar yetkisi daha çok anne-baba ortak veya sadece baba şeklinde gerçekleşmektedir.

Tatil alt kararların demografik faktörlerle olan ilişkisine bakıldığında, aralarında istatistiksel olarak anlamlı ilişkilerin olduğu $(\mathrm{p}<0,05)$ ortaya çıkmıştır. Buna göre, eğitim seviyesi arttıkça, çocuğun aile içindeki etki düzeyi de artmaktadır. Yani, lisansüstü ve lisans seviyesine sahip anne-babalar çocuklarını çok daha fazla dikkate almaktadırlar. Benzer şekilde gelir seviyesi arttıkça da çocuğun aile içinde sözünün dinlenmesi artmaktadır. Yine, tek gelirli ailelere göre çift gelirli ailelerde çocuk çok daha fazla söz sahibi olmaktadır. Literatürde de çift gelirli ailelerde çocukların aile kararlarında daha etkili olduğuna dair kanıtlar bulunmaktadır (Labrecque ve Ricard, 2001; Wang ve diğ., 2004; Chen ve diğ., 2015; Khoo-Lattimore, 2015). Yılda çıkılan tatil sayısı ile tatil alt kararlarında çocuğun etkisini ortalamalar itibariyle karşılaştırdığımızda birden fazla (yılda iki kez, üç kez ve üçten fazla) tatil yapanların, yılda bir kez tatil yapanlardan çok daha fazla çocuklarını dinlediği ortaya çıkmıştır. Tatile çıkma sayısı arttıkça çocuğun tatil kararlarındaki etkisi de artmaktadır.

Araştırmada otel ve tatil yeri seçiminde ve diğer tatil kararlarında anne-babaların çocuklarına yönelik hangi fayda ve beklentiler içinde olduklarını ve neyi önemsediklerine dair sorulan 21 ifadeden en yüksek ortalamaya ve en olumlu katılma düzeyine sahip ifadeler şu şekilde ortaya çıkmıştır: "Çocuklara özel aktivitelerin ve animasyonların olması tatil yeri tercihimizi etkiler $(4,07)$ ", "Çocuklara uygun havuzun ve su kaydırağının olması gidilecek yer tercihimizi etkiler $(4,01)$ ", "Çocuklara uygun spor aktivitelerinin olduğu yerleri tercih ederiz (4,02)", "Kendimizden ziyade tatilde çocuğumuzun eğlenmesini/mutlu olmasını isteriz $(4,14)$ ", “Tatil kararlarımızda çocuğumuzun bol bol koşup oynayacağı açık alanları tercih ederiz $(4,20)$ " ve "Çocuğumun tatil sonrası hatırlayacağı birkaç eşya almak hoşuma gider $(4,13)$ ”. Bu ifadelerden anlaşılan ebeveynlerin tatilden duyacakları memnuniyetin çocukların memnuniyetine bağlı olduğu ve onların tatilden mutlu olarak dönmelerinin anne-babaları da mutlu ettiği (Li ve diğ., 2017) sonucu çıkarılabilir. Turizm yöneticileri tutundurma faaliyetlerini ailenin demografik özelliklerine, çocuğun yaşına ve evde tatil kararını kimin verdiğine göre ayrı ayrı uygulamaları önerilebilir.

\section{Gelecek Çalışmalar için Öneriler}

Gelecekte ailelerin tatil kararlarında çocuğun etkisini araştıracak olan çalışmalara şu önerilerde bulunulabilir. 
-Aileler gelir düzeyine, çocuk sayısına ve düzenli tatil yapıp yapmadıklarına göre ayrılabilir. Örneğin sadece yüksek gelirli, orta ve düşük gelirli aileler üzerinde çalışma yapılarak çocuğun tatil kararlarına olan etkisi aile geliri ile karşılaştırılabilir. Benzer şekilde tek çocuklu aileler ile birden fazla çocuğu olan aileler aynı çalışma içerisinde değerlendirilebilir. Çünkü bu araştırma sonucunda aile gelirine ve çocuk sayısına göre tatil kararlarında çocuğun etkisi ve rolünün farklılaştığı ortaya çıkmıştır.

-İleride yapılacak çalışmalarda uygulanacak anket doğrudan çocukların kendisine yapılabilir. Böylece potansiyel bir tüketici gözüyle bakılan çocukların kendi düşünceleri öğrenilebilir. Buna yönelik olarak geliştirilecek ölçekler tatil kararlarında çocuğun nelere dikkat ettiğinin bilinmesi açısından kritik önem taşıyabilir.

-Ailenin tatil kararlarında çocuğun etkisinin araştırıldığı çalışmalarda kültür değişkeni araştırmaya dahil edilebilir. Farklı şehirlerde ve farklı bölgelerde yapılacak araştırmalar, bu alandaki bulguları genişletebilir. Örneğin bu çalışma yalnızca Akçakoca'da yapılmıştır. Farklı özelliklerdeki evren ve örneklemler farklı ve değerli sonuçlara ulaşmayı sağlayabilir.

-Verilebilecek son öneri ise yaş gruplarına yönelik olabilir. Bu araştırmada 2-6 yaş arası çocukların tatil kararlarına olan etkileri incelenmiştir. Başka çalışmalarda yaş grupları arasında karşılaştırmalar yapılabilir ve bu yaş gruplarından hangisinin çok daha fazla dikkate alınacağı ve ailelerin tatil kararlarında hangi yaş gruplarındaki çocukların daha etkili olduğu öğrenilebilir. Zira böylesi bir sonuç, turizm yöneticileri açısından dikkate değer bir sonuç olacaktır. Reklam, pazarlama, sponsorluk ve diğer iletişim araçlarının etkin ve verimli kullanımı, otel yöneticilerinin strateji ve politikalarının yeniden düzenlenmesi, bazı otellerin kendilerini konumlandırmaları gibi birçok konuda elde edilecek bulgular bir rehber niteliği taşıyabilir ve yöneticilere bir yol haritası sunabilir.

\section{Çalışmanın Kısıtları}

Araştırmanın en önemli kısıtı sadece Akçakoca'da yapılmış olmasıdır. Farklı evren ve o evrenden seçilecek farklı özelliklerdeki örneklemler üzerinde yapılacak çalışmalar bu alandaki bulguları genişletebilir. Ayrıca çalışmanın belli bir yaş aralığındaki çocuklu ailelere yapılmış olması da bir diğer kısıttır. Anketin doğrudan çocuklara değil de onların ebeveynlerine uygulanmış olması yine araştırmanın kısıtları arasında değerlendirilebilir. 


\section{KAYNAKÇA}

Alagöz, S. B. (2009). “Çocukerkil Aile Sisteminde Satın Alma Davranışı”, S.Ü. İİBF Sosyal ve Ekonomik Araştırmalar Dergisi, 1 (16), ss.316-338.

Altunışık, R. \& Coşkun, R. \& Bayraktaroğlu, S. ve Yıldırım, Y. (2010). Sosyal Bilimlerde Araştırma Yöntemleri: SPSS Uygulamal1, 6.Baskı, Sakarya: Sakarya Kitapevi

Ashraf, M. ve Khan, K.M. (2016). "Spousal role and family vacation decision making in India”, International Journal of Business and Systems Research, 10 (1), ss. 45-61.

Ateşoğlu, İ. ve Türkkahraman, M. (2009). Çocukların Tüketici Olarak Sosyalleşmesi, Süleyman Demirel Üniversitesi İİBF Dergisi, 14 (3), ss.215-228

Aygün, İ. (2006). Çocukların Ailede Satın Alma Kararları Üzerine Etkileri ve Bir Uygulama, Gebze Yüksek Teknoloji Enstitüsü, SBE Yüksek Lisans Tezi, Gebze.

Aymankuy, Y. ve Ceylan, U. (2013). "Ailelerin Turistik Ürün Satın Alma Karar Sürecinde Çocukların Rolü: Yerli Turistler Üzerinde Bir Araştırma”, Elektronik Sosyal Bilimler Dergisi, 12 (45), ss.105-122.

Bacıoğlu, S. (2017). “0-6 Yaş Bebeklik ve Erken Çocukluk Dönemi Uyum ve Davranış Problemleri” (İçinde: Yaşam Dönemleri ve Uyum Sorunları., Ed: Firdevs Savi Çakar), Ankara: Pegem Akademi

Bronner, F. ve de Hoog, R. (2008). "Agreement and disagreement in family vacation decision making", Tourism Management, 29 (5), ss.967-979.

Carr, N. (2006). "A comparison of adolescents' and parents' holiday motivations and desires", Tourism and Hospitality Research, 6 (2), ss.129-142.

Chen, Y. S. \& Lehto, X. \& Behnke, C. ve Tang C. H. (2015), “Investigating Children's Role in Family Dining-Out Choices: Evidence From a Casual Dining Restaurant", Journal of Hospitality Marketing \& Management

Cüceloğlu, D. (2012). İnsan ve Davranışı, 22.Basım, İstanbul: Remzi Kitapevi

Çakıcı, C. ve İyitoğlu, V. (2011). “Tatil Kararlarında Çocukların Etkisine Göre Antalya’ya Gelen Ailelerin Pazar Bölümlerine Ayrılması, Pazarlama ve Pazarlama Araştırmaları Dergisi (8), ss.1-20.

Çakıcı, C. ve İyitoğlu, V. (2012). “Tatil Kararlarında Aile Üyelerinin Rolü: Antalya İlinde Tatil Yapan Aileler Üzerinde Bir Araştırma”, Ç.Ü. Sosyal Bilimler Enstitüsü Dergisi, 21 (1), ss.117-134. 
Emir, O. ve Pekyaman, A. (2010). "Çocuklu Ailelerin Otel İşletmesi Seçiminde Etkili Olan Faktörler: Afyonkarahisar'da Bir Uygulama”, Yönetim ve Ekonomi Dergisi, 17 (2), ss.159-181.

Gülerarslan, A. (2011). “Tüketici Olarak Çocuk ve Ailenin Satın Alma Kararlarına Etkisi”, Selçuk Üniversitesi İletişim Fakültesi Dergisi, 6 (4), ss.126-137.

Hallman, B. C. ve Benbow, S. M. P. (2007). "Family leisure, family photography and zoos: Exploring the emotional geographies of families", Social and Cultural Geography, 8 (6), ss. $871-888$

Henderson, K. A. \& Whitaker, L. S. \& Bialeschki, M.D. \& Scanlin, M. M., ve Thurber, C. (2007). "Summer camp experiences parental perceptions of youth development outcomes”, Journal of Family Issues, 28 (8), ss.987-1007.

İnanç Yazgan, B. \& Bilgin, M. ve Atıcı Kılıç, M. (2015). Gelişim psikolojisi, 10.Basım, Ankara: Pegem Akademi

Jeevananda, S., ve Kumar, S. (2012). "Degree of children influence on parents buying decision Process", European Journal of Business and Management, 4 (14), ss.49-57.

John, D. R. (1999). "Consumer socialization of children: A retrospective look at twenty five years of research", Journal of Consumer Research, 26(3), ss.183-213.

Kandır, A. ve Alpan, Y. (2008). "Okul öncesi dönemde sosyal-duygusal gelişime annebaba davranışlarının etkisi” Aile ve Toplum Dergisi, 10 (4), ss.33-38

Karadağ, L. (2011). “Çocuk Pazarları, Çocukların Aile Kararlarına Etkisi: Marmaris Örneği”, İstanbul Aydın Üniversitesi Dergisi, 1 (9), ss.73-92.

Khoo-Lattimore, C. \& Prayag, G ve Cheah, B. (2015). Kids on Board: Exploring the Choice Process and Vacation Needs of Asian Parents with Young Children in Resort Hotels, Journal of Hospitality Marketing \& Management, ss. 1-21

Khoo-Lattimore, C. (2015). "Kids on board: Methodological challenges, concerns and clarifications when including young children's voices in tourism research", Current Issues in Tourism Research, 18 (9), ss.845-858

Labrecque, J., \& Ricard, L. (2001). “Children's influence on family decision-making: A restaurant study”, Journal of Business Research, 54(2), 173-176.

Lawlor, M. A. ve Prothero, A. (2011). Pester power - A battle of wills between children and their parents. Journal of Marketing Management, 27(5-6), ss.561-581

Lehto, X. Y. \& Fu, X. \& Li, H. ve Zhou, L. (2013). "Vacation Benefits and Activities: 
Understanding Chinese Family Travelers", Journal of Hospitality \& Tourism Research, 20 (10), ss. $1-28$

Lehto, X. Y. \& Choi, S. \& Lin, Y. ve MacDermid, S. M. (2009). "Vacation and family functioning", Annals of Tourism Research, 36 (3), ss.459-479

Li, M. \& Wang, D. \& Xu, W. ve Mao, Z. E. (2017). "Motivation for family vacations with young children: anecdotes from the Internet", Journal of Travel \& Tourism Marketing, ss. 1-11

Madran, C. ve Bozyiğit, S. (2013). "Çocukların tüketici olarak sosyalleşme süreci”, Çağ Üniversitesi Sosyal Bilimler Dergisi, 10 (1), ss.71-95.

Mallery, P., ve George, D. (2000) SPSS for windows step by step (3rd ed.)., Allyn \& Bacon

Memiș, S. (2016). “Tatil Yeri Seçiminde Etkili Olan Faktörler: Yerli Turistler Üzerinde Bir Araștırma”, Kesit Akademik Dergisi, 2 (4), ss.212-226.

Nanda, D. \& Hu, C.ve Bai, B. (2006). "Exploring family roles in purchasing decisions during vacation planning", Journal of Travel \& Tourism Marketing, 20 (3), ss.107-125.

Segumpan, R. G. \& Zahari, J. S. A. ve Jamaluddin, M. M. (2008). “Tourism among Families in Northern Peninsular Malaysia”, Asia-Pacific Social Science Review, 8 (2), ss.129-139.

Tabachnick, B. G. ve Fidell, L. S. (1996) Using multivariate statistics (3rd ed.). Boston: Allyn \& Bacon

Therkelsen, A. (2010). "Deciding on family holidays- role distribution and strategies in use”, Journal of Travel \& Tourism Marketing, 27 (8), ss.765-779.

Thornton, P. R. \& Shaw, G. ve Williams, A. M. (1997). “Tourist group holiday decision making and behaviour: The influences of children", Tourism Management, 18 (5), ss.287 297.

Tripathi, P. ve Sengupta, A. (2011). "Increasing role of children in family purchase decisions", Indian Journal of Marketing, 41 (6).

Türedi, Ö. (2009). Turizm Pazarlaması Açısından Tatil Yeri Seçiminde Etkili Olan Faktörler, Marmara Üniversitesi SBE, İşletme Anabilim Dalı, Yüksek Lisans Tezi, İstanbul.

Wang, K. C. \& Hsieh, A. T. \& Yeh, Y.C. ve Tsai, C.W. (2004). "Who is the decision-maker: the parents or the child in group package tours?", Tourism Management, 25 (2), ss.183194.

Webster, S. (2012). Consumer kids and tourists - Creatively marketing a city to young 
tourists. In H. Schanzel, I. Yeoman \& E. Backer (Eds.), Family tourism: Multidisciplinary perspectives. Bristol, UK: Channel View

Yavuzer, H. (1987). Çocuk psikolojisi. İstanbul: Remzi Kitabevi

Statısta (2020), World population by age and region, https://www.statista.com/ statistics/265759/world-population-by-age-and-region/\#statisticContainer (Erişim Tarihi: 15.10 .2020 )

Türkiye İstatistik Kurumu (TÜİK), İstatistiklerle Çocuk, Haber Bülteni http://www.tuik. gov.tr/PreIstatistikTablo.do?istab_id=595 (Erişim Tarihi: 15.02.2018) 
